\title{
RC コアウォールシステム DEVELOPMENT AND PROOF の開発亡実証 \\ OF THE RC CORE WALL SYSTEM
}

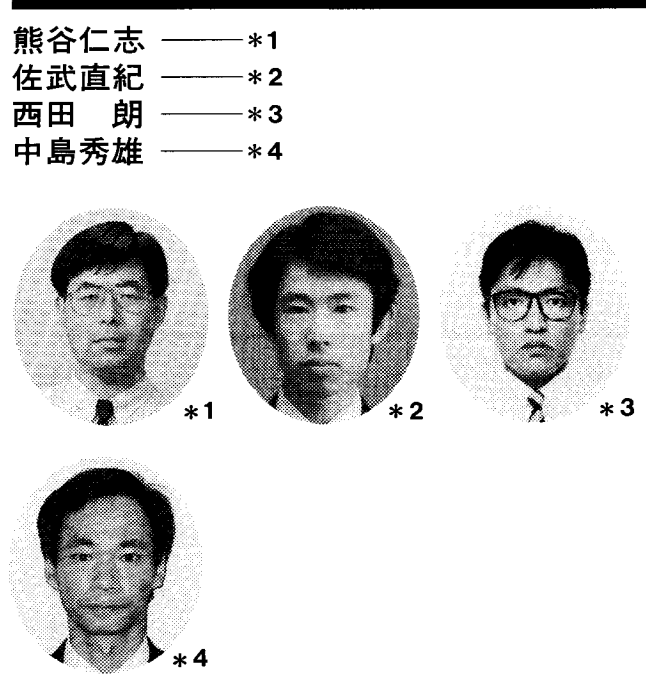

キーワード

混合構造, 高強度コンクリート, RC コアウォール, $\mathrm{X}$ 形配筋, 3 次元地震応答解 析

\section{Hitoshi KUMAGAI \\ Naoki SATAKE \\ Akira NISHIDA \\ Hideo NAKASHIMA}

The structural system composed of reinforced concrete (RC) shear wall and steel frame is presented. A series of experiment conceming the quality control of the high strength concrete and structural behavior of the $\mathrm{RC}$ shear wall under seismic load had been performed to develop this system. This system was applied to the actual 25-story building consequently.

\section{1.はじめに}

最近、鉄筋コンクリート造と鉄骨造を組み合わせて用いそのお互 いの特長を発揮させることをねらいとした混合構造が注目を集めて いる。筆者らは、高層建築物のコア部分を鉄筋コンクリート造耐震 壁（RＣコアウォール）とし、梁拉よび周辺フレームを鉄骨造とし た混合構造「R Cコアウォールシステム」を開発した。本システム には以下のような特長がある。

・コア部と周辺部を区画する建築計画上必要な壁をそのまま構造体 として利用できること。

・ R C コアウォールが我平力の大半を負担するため、柱が地震力か ら解放され、自由なレイアウトが可能であること。

鉄骨造に比べて建物の剛性が高く、風摇れをほほ半隇できること。

・R C 造に比べて、長スパンが可能であること。

ＲＣコアウォールをセルフクライミング式大型型染を用いて先行 施工することによって、鉄骨造と同等の工期で施工できること。

・建物の鉄骨量を低隇し、コストダウンが図れること。

このような構造形式は海外ではよく採用されているが、地震国で ある日本で採用するには R C コアウォールの耐力・靱性の向上など さまざまな解決すべき課題があった。

\section{Keywords :}

Hybrid structure, High strength concrete, RC core wall, Diagonal reinforcement, 3-D earthquake response analysis
*1 清水建設 (株) 技術研究所 (干135 江東区越中島3-4-17)

*2 清水建設(株)設計本部 工博

*3 清水建設(株)技術研究所

*4 清水建設 $($ 株)設計本部 設計長
本報告は、筆者らが本システムを実用化するために行った一連の 技術開発1) 7) と実建物の施工を通じたその実証の過程をまとめ、 報告するものである。

2. RCコアウォールシステムに関する技術的検討

\subsection{R Cコアウォールシステムの課題とその解決策}

RCコアウォールシステムの構造概念図を図 1 に示す。本システ ムの開発のために解決しなければならない課題として、(1)R C コア ウォールがスレンダーになり（高さ・幅比が7程度）、転倒モーメ ントによる圧縮・引張あるいは基礎の浮き上がりが顕著になること、 (2)鉄骨造に比べて大地震時のエネルギー吸収能力がそしくなること、 などが予想された。

そこで(1)の解決策として、RCコアウォールの圧壊を防止して耐 力・靶性を確保するため、低層部に設計基準強度 $600 \mathrm{kgf} / \mathrm{cm}^{2}$ クラス の高強度コンクリートを用い、壁縦筋には高強度太径鉄筋（D38、 SD390）を用いることとした。またR Cコアウォール頂部にはハッ トトラス（図 1 参照）を設けることにより、全体の転倒モーメント の約 $25 \%$ 周辺フレームの軸力として伝達させることができる。(2) の解決策としては、境界梁にX形筋を配し、大地震時にはこれが曲 げ降伏するように計画した。壁厚と同じ梁幅の中に配筋を納めるた 


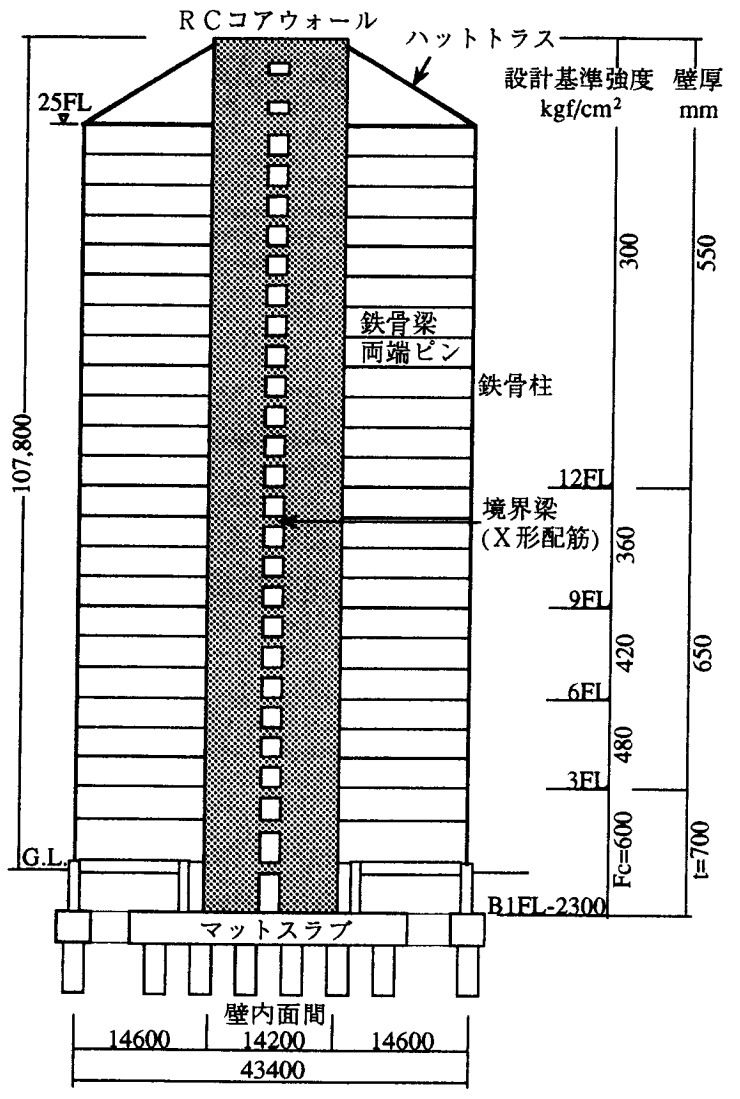

図 1 構造概念図 (海老名プライムタワーの例)

めX形筋には高強度太径鉄筋（D41、SD490）を用いることとした。 高強度コンクリートの実用化や、部材の耐力・変形性能の把握を 目的に実施した実験の結果を次に示す。

\section{2 高強度コンクリートの調合実験}

既往の研究では設計基準強度 $600 \mathrm{kgf} / \mathrm{cm}^{2}$ クラスの高強度コンクリ 一トでは、構造体は初期に水和熱によって高温を受けるため、構造 体コンクリート強度が標準養生強度よりも低くなることが指摘され ている。したがって、構造体コンクリート強度を確保するためには、 初期の温度履歴の影響を考虑して調合を決定しなければならない。 そこで図 2 に示すような一連の実験を実施した1),2)。

実機プラントを用いた試験練りを行い、圧縮強度と水セメント比 の関係を調べた。これに合わせて厚さ $700 \mathrm{~mm}$ の壁モデル試験体に 水セメント比 $30 \%$ のンクリートを打設し、その温度履歴を測定し た。打設は 7 月中旬に行われたが、試験体中心部の温度は最高81.4 ○に達した。この温度履歴を追随させた水槽内で養生した $\phi 100 \times$ 200供試体（以下、温度追随養生という）の強度発現と標準養生供 試体の強度発現を比較したものを図 3 に示す。材跉28、56日におい て温度追随盖生強度は標準養生強度を下回っている。材龄28日では、 標準養生強度 $\left(770 \mathrm{kgf} / \mathrm{cm}^{2}\right)$ は温度追随養生強度 $\left(665 \mathrm{kgf} / \mathrm{cm}^{2}\right)$ の 1.16倍となった。

この結果を踏まえ、管理材齢28日の調合を(1)式のように定めた。 $\alpha$ を前述の1.16倍とすると、調合強度は $792 \mathrm{kgf} / \mathrm{cm}^{2}$ となり、実施工 における水セメント比を $28.5 \%$ に決定した。

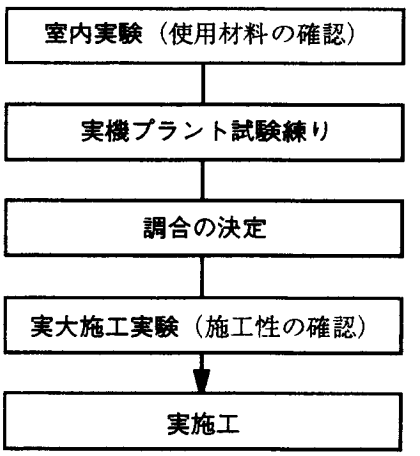

図 2 高強度コンクリート施工までの流れ

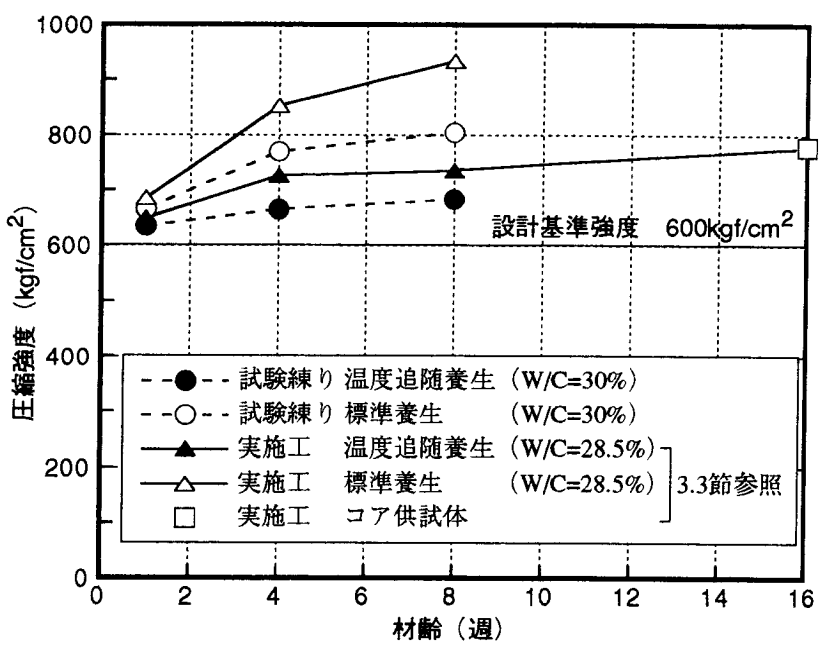

図 3 盖生方法による強度発現の比較

$$
\begin{aligned}
\mathrm{F} 28=\alpha & (\mathrm{Fc}+1.73 \sigma) \\
& \mathrm{F} 28: \text { 調合強度 } \\
\alpha & : \text { 標準養生強度 } / \text { 構造体コンクリート強度 } \\
\mathrm{Fc} & : \text { 設計基準強度 }\left(=600 \mathrm{kgf} / \mathrm{cm}^{2}\right) \\
\sigma & : \text { 標準偏差 }\left(=0.08 \mathrm{Fc}=48 \mathrm{kgf} / \mathrm{cm}^{2}\right)
\end{aligned}
$$

\section{$2.3 \mathrm{~L}$ 形壁の $45^{\circ}$ 方向加力実験}

R C コアウォールは $45^{\circ}$ 方向に水平力を受けた場合に最も高い軸 力が作用する。そこで建物の 1 ～階部分を想定した L 形壁の $45^{\circ}$ 方向加力実験を実施し、R C コアウォールの耐力・勒性を確認する こととした3)。

試験体は図 4 に示すような約 $1 / 7$ 縮小モデルで、壁厚 $100 \mathrm{~mm}$ 、 一辺の長さ $800 \mathrm{~mm}$ である。試験部には圧縮強度 $\sigma \mathrm{B}=531 \mathrm{kgf} / \mathrm{cm}^{2}$ の 高強度コンクリートを用いた。実際の壁の配筋を一般部縦筋 2-D38 @175（SD390）、コーナー部縦筋3-D38@175（SD390）、横筋2D25@150（SD345）とし、これと同等の鉄筋比になるように一般部

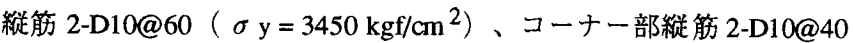
$\left(\sigma \mathrm{y}=3450 \mathrm{kgf} / \mathrm{cm}^{2}\right)$ 、横筋2-D6@65 $\left(\sigma \mathrm{y}=3790 \mathrm{kgf} / \mathrm{cm}^{2}\right)$ とした。 コーナー部が曲げ圧縮となるときに圧縮軸力を、曲げ引張となると きに引張軸力を作用させた。水平力と軸力の比率は子め行った静的 増分解析および地震応答解析の結果から図 5 のTES T-1、TEST-2の 2 種類とした。

実験結果の一例を図 6 および図 7 に示す。最終的にTEST-2の加 力で压縮軸力 $0.6 \mathrm{Ac} \sigma \mathrm{B}$ を保持しながら水平力を加えると、部材角 
1/67でコーナー部が圧壊し酎力が低下した。図中に○で示したのは、 曲げ解析結果（せん断変形は弾性変形分を加算）である。解析では 部材を材長方向に要素分割し、各要素の軸力と曲げモーメントの組 み合わせについて曲率および軸ひずみを計算し、これを積分して曲 げ変形および軸変形を求めている。解析值によって実験結果を概ね 評価できている。実建物の設計時にはこの解析に基づいて復元力特 性および降伏曲面を決定することにした。

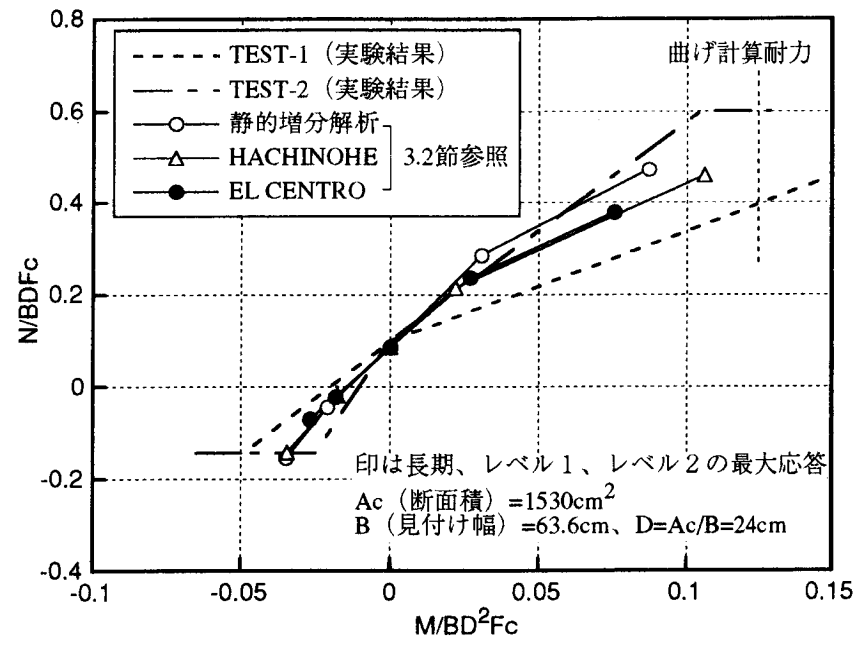

図 5 軸力と曲げモーメントの相関

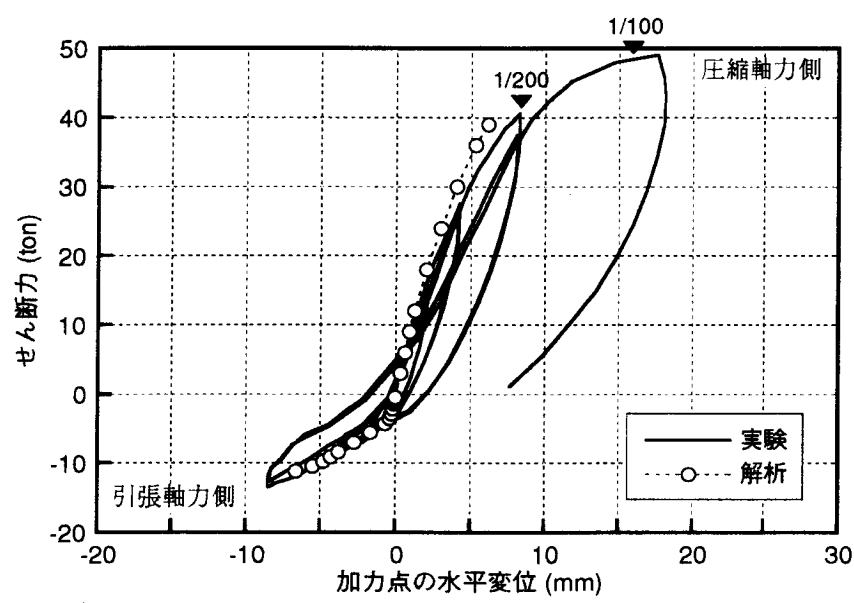

図 6 せん断力と水平変位の関係（TEST-1）

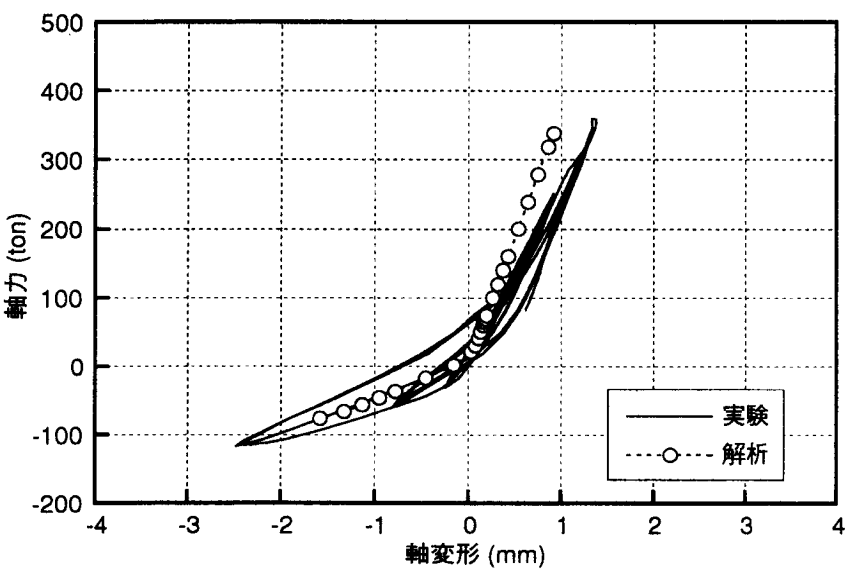

図 7 軸力と軸変形の関係（TEST-1）

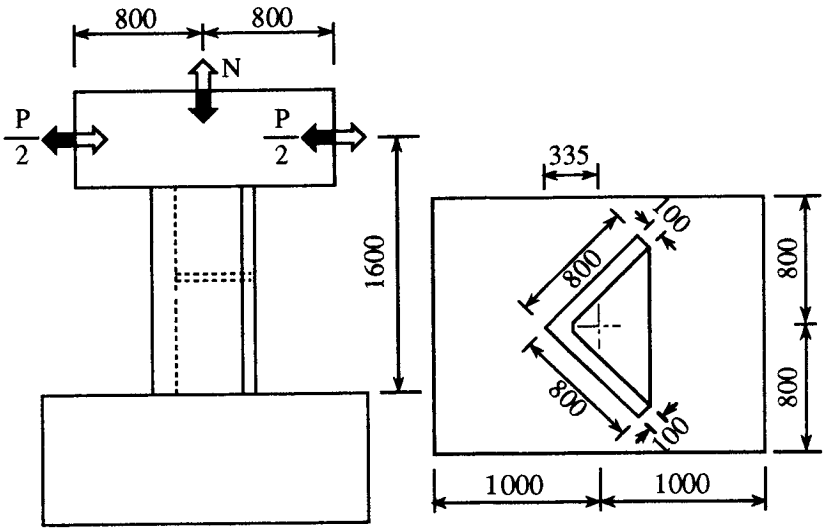

図 4 L 形壁試験体

\subsection{X形配筋梁の曲げせん断実験}

本システムの境界梁には高強度太径鉄筋（D41、SD490）を用い ており、大地震時にはこの境界梁が曲げ降伏してエネルギーを吸収 するように計画している。そこで塑性化が最も進行する中間階部分 を想定したX 形配筋梁試験体の曲げせん断実験を実施し、その耐 力・変形能力を確認することとした3)。

試験体は図 8 に示すような約 $1 / 2$ 縮小モデルで、幅 $300 \mathrm{~mm}$ 、せ い $600 \mathrm{~mm}$ 、せん断スパン比が 0.75 の短スパン梁である。試験部には 压縮強度 $\sigma \mathrm{B}=381 \mathrm{kgf} / \mathrm{cm}^{2}$ のコンクリートを用いている。X形筋には $8-\mathrm{D} 19\left(\sigma \mathrm{xy}=5840 \mathrm{kgf} / \mathrm{cm}^{2}\right)$ 、平行筋には $4-\mathrm{D} 13 （ \sigma \mathrm{py}=3830$ $\left.\mathrm{kgf} / \mathrm{cm}^{2}\right)$ を用いた。計算曲げ耐力上の $80 \%$ 以上がX形筋によって 負担されるようになっている。

せん断力と変形の関係を図 9 に示す。平行筋は部材角 $1 / 300$ 程度 で降伏したがせん断力〜変形関係にほとんど変化はなく、最外縁の $\mathrm{X}$ 形筋が部材角 $1 / 140$ 程度で降伏し、部材角 $1 / 120$ 程度になるとせん 断力の上昇が頭打ちとなった。最終的に部材角 $1 / 15$ 程度まで加力し たがせん断力は上昇し続けていた。塑性率にすると 8 以上あり、非 常に変形能力に富んだ部材であることが確認された。図中の点線は 復元力特性のスケルトンで、Tri-linearでモデル化した。第一折れ点 は曲げひび割れ発生時点で菅野式で求めた。第二折れ点は曲げ降伏 時点であるが、この時の変形は部材の軸変形を無視しX形筋をブレ ースに置換したモデルで求め、耐力は(2)式で求めた。

$\mathrm{Qu}=(0.9$ apt $\sigma \mathrm{py} \mathrm{dp}+0.9$ axt $\sigma \mathrm{xy} \mathrm{dx} \cos \theta) /(0.5 \mathrm{~L}) \cdots(2)$ $\mathrm{apt}$ : 平行筋断面積、 $\mathrm{axt}$ : X 形筋断面積、 $\theta: \mathrm{X}$ 形筋傾斜角 $\sigma \mathrm{py}$ : 平行筋降伏強度、 $\sigma \mathrm{xy}: \mathrm{X}$ 形筋降伏強度 $\mathrm{dp}$ : 平行筋有効せい、 $\mathrm{dx}: \mathrm{X}$ 形筋有効せい

今回設定した復元力モデルと実験結果は良く一致している。

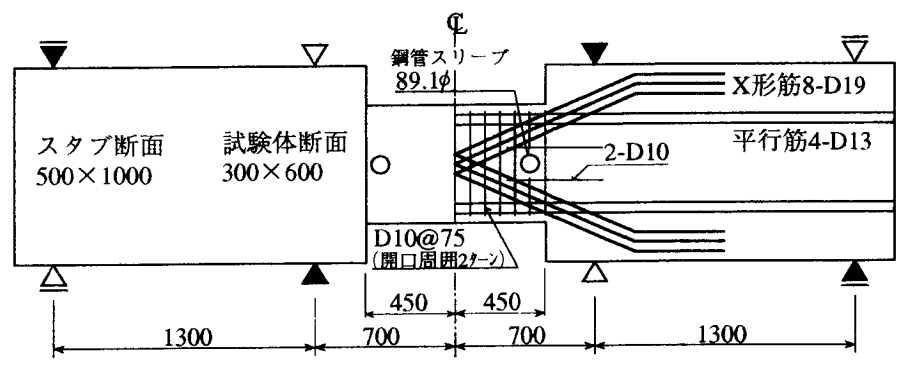

図 8 X形配筋梁試験体 


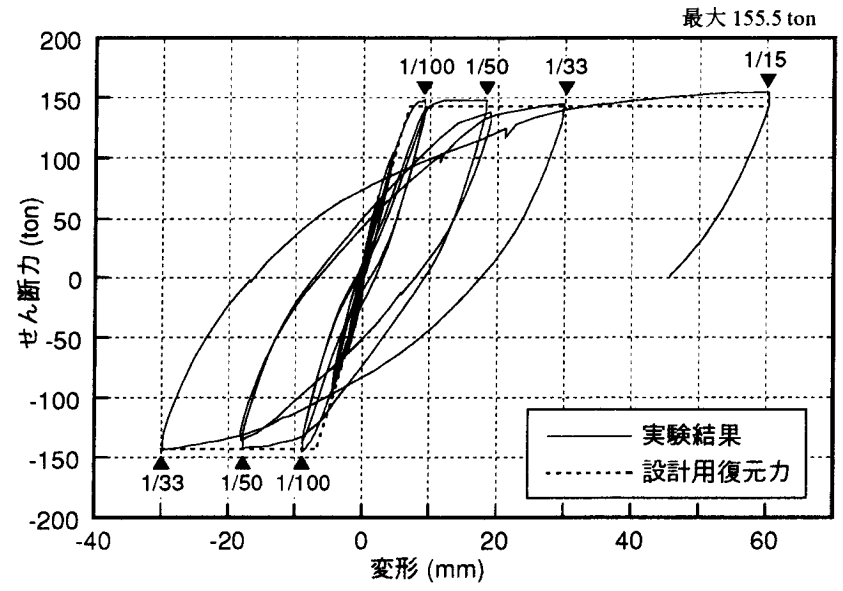

図 9 せん断力と変形の関係

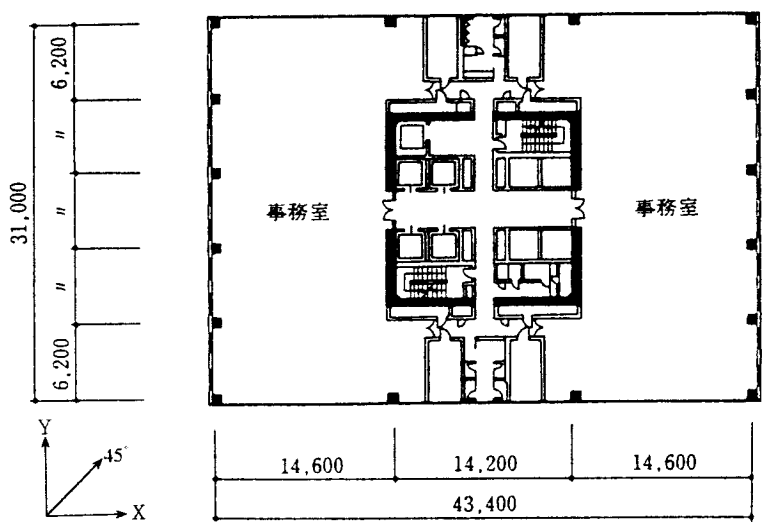

図10 基㔼階平面図

\section{3 実建物への適用}

\section{1 建物概要}

2 章で述べたような技術的検討の結果、本システムの実用化に目 処が立ち、「海老名プライムタワー」に適用することができた。そ の基準階の平面図を図10に、構造概念図を図1に示す。建物概要は 以下のと抽である。

所在地 : 神奈川県海老名市中央二丁目

階 数 : 地下 1 階、地上 25 階、塔屋 1 階

敷地面積: $12,016 \mathrm{~m}^{2}$

総床面積: $57,319 \mathrm{~m}^{2}$

最高高さ： $107.8 \mathrm{~m}$

基準階 : 床面積（オフィス棟） $1,393 \mathrm{~m}^{2}$ 、階高 $3.90 \mathrm{~m}$

構 造 : 鉄筋コンクリート造および鉄骨造

基 礎：アースドリル拡底杭（先端GL-27m）

設 計 : 清水建設（株）一級建築士事務所

施 工 : 清水建設 (株) 横浜支店

工 期 : 平成 4 年10月～ 7 年 6 月

\section{2 構造設計概要}

本建物は中心部の R C コアウォールと外周部の鉄骨フレームによ って構成されており、建物に作用する地震時せん断力の約 $90 \%$ を アウォールが負担するように設計されている。またレベル 2 地震に
対してはRCコアウォール脚部と境界梁端部に曲げ降伏ヒンジが形 成されることを想定している。そこで各部材の挙動については図11 に示すような 3 次元フレームモデルを用いた弾塑性地震応答解析に

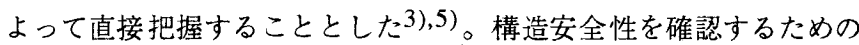
クライテリアについても表 1 のよう各部材ごとに定めている。

$\mathrm{X} 、 \mathrm{Y}$ 方向解析時には対称条件を利用した $1 / 2$ モデル、 $45^{\circ}$ 方 向解析時にはフルモデルを用いた。コアウォールと境界梁は線材に 置換した。予備検討としてFEM解析を行い、X、Y方向解析時のコ アウォールのフランジの有効幅は全幅の $80 \%$ 、剛域は梁せいの $1 / 4$ 入った所までとした。各要素の復元力モデルおよび降伏曲面は 2 章 の検討結果をもとに決定した。入力地震動はEL CENTRO NS (1940)、 TAFT EW (1952)、HACHINOHE NS (1968)、TOKYO101 NS (1956)

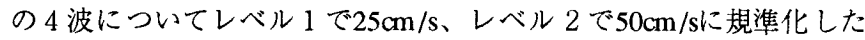
ものを用いた。基礎部については杭バネを考慮し、隇衰は瞬間剛性 比例型 $\left(\mathrm{h}_{1}=3 \%\right)$ とした。

固有值解析の結果を図12に示す。X力向の3 次モードには周辺フ レームがコアウォールに関して逆対称に上下に振動するモードが、 Z方向の 1 次モードには周辺フレームがコアウォールに関して対称 に上下に振動するモードが現われている。

以下最も応答値の大きかったHACHINOHEを用いた地震応答解析 結果について述べる。レベル 2 地震に対する最大応答層間変形角は $\mathrm{X}$ 方向で1/100、Y方向で1/118といずれも1/100以下に納まっている。 $\mathrm{X}$ 万向レベル 2 地震に対するヒンジ発生状況を図13に示す。境界梁 の塑性率は最大で1.46（X 方向13階）であり、クライテリアの4.0 を下回っている。 $45^{\circ}$ 方向解析時のコアウォールの軸力と曲げモー メントの相関を図 5 中に示すが、レベル 2 地震に対する最大曲げモ ーメントは実験で確認された範囲内である。最大圧縮軸力比は最大

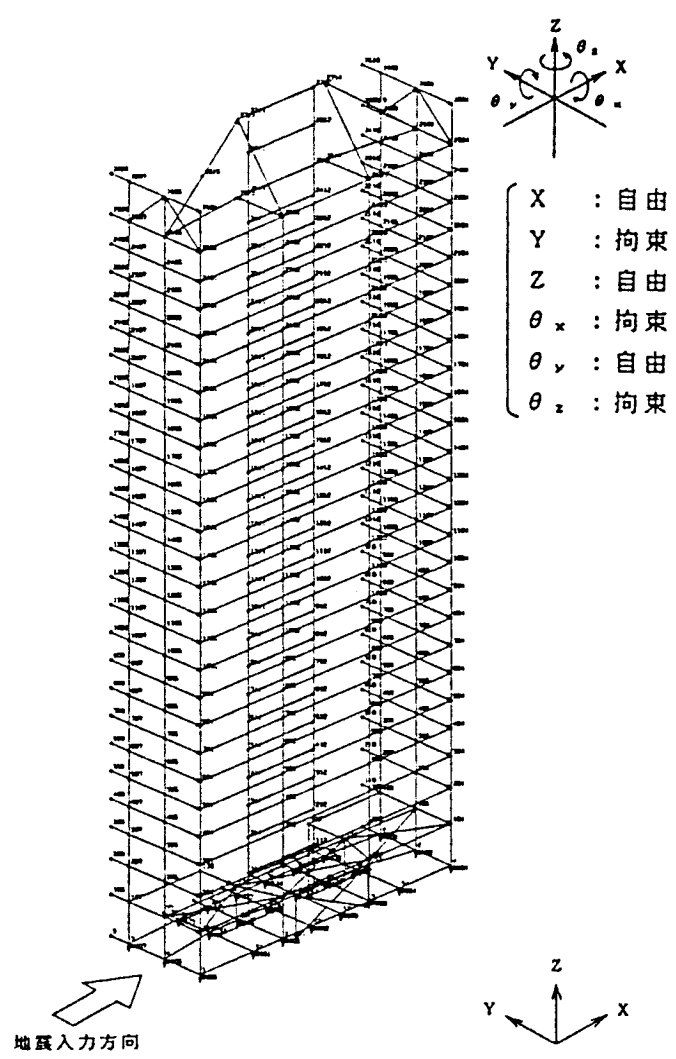

図11 X方向解析モデル図 (1/2モデル) 


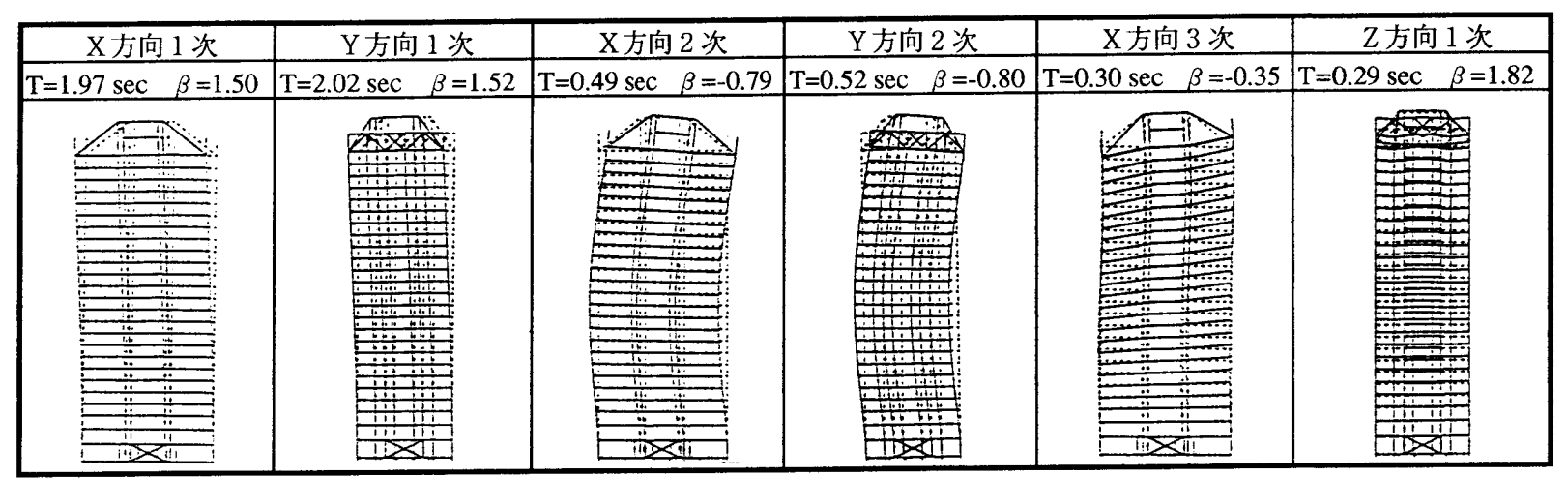

図12 固有値解析結果

で0.547（3 階）であり、クライテリアの0.6を下回っている。また この時の壁脚の部材角は1/573 (压縮軸力側) であり、クライテリ アの1/150を下回っている。境界梁抢よびコアウォール脚部は限界 変形能力に対して十分な余裕度を有していると考えられる。

図14に静的増分解析による1次設計時の層せん断力分布を示す。 層せん断力の約 $90 \%$ を音ウォールが負担していることが分かる。

\section{3 高強度コンクリートの施工結果}

設計基準強度 $600 \mathrm{kgf} / \mathrm{cm}^{2}$ のコンクリートの打設は、平成 5 年 9 月 から平成 6 年 1 月にわたって行われ、総打設量は $620 \mathrm{~m}^{3}$ であった。 目標スランプは $23 \mathrm{~cm}$ 、目標空気量は $2 \%$ ある。コンクリートはポ ンプ压送を行い、中間開口のあるトレミー管を用いて打設したが、 施工性は良好であった2)。

コアウォール L 形壁のコーナー中心部に熱電対を取り付け、温度 追随養生に用いた。夏期 $(9 / 20)$ の打設では、最高温度は $85.7^{\circ} \mathrm{C} に$ 達 していた。このときの標準養生供試体と温度追随養生供試体の強度

表1 部材の応力・恋形に関するクライテリア（レベル 2)

\begin{tabular}{|c|c|c|}
\hline & コアウォール & 境界梁 \\
\hline 軸 & 压縮軸力 $<0.6 \mathrm{Fc} \mathrm{Ac}$ & - \\
\hline せん断力 & $\begin{array}{c}\text { 終局強度型指針" } \text { による } \\
\text { せん断耐力の } 1 / 1.3 \text { 以下 }\end{array}$ & - \\
\hline 変 形 & $\begin{array}{c}\text { ヒンジ部（壁脚・壁頭） } \\
\text { 部材角＜1/150 }\end{array}$ & 塑性率 $<4.0$ \\
\hline
\end{tabular}
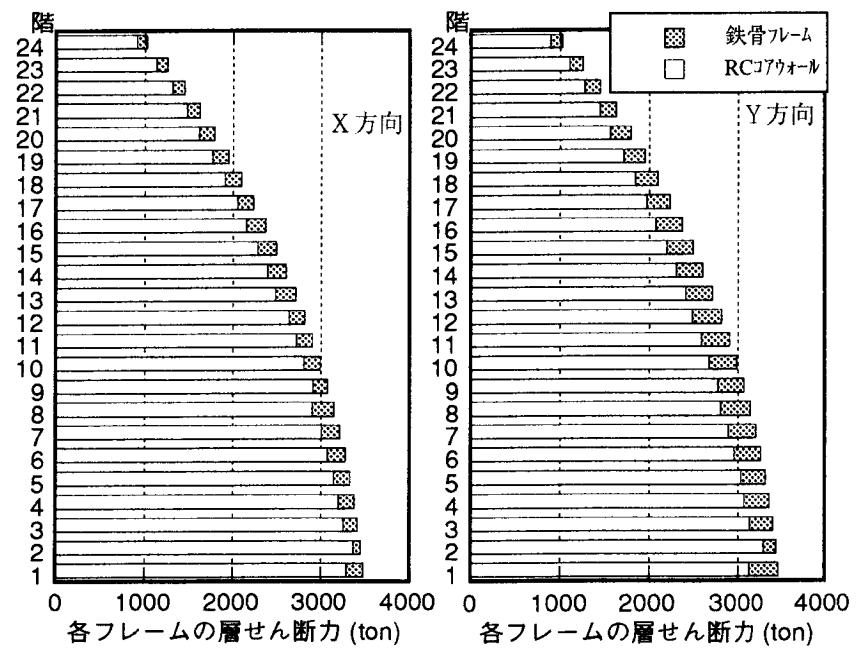

図14 RCコアウォールと鉄骨フレームのせん断力分担

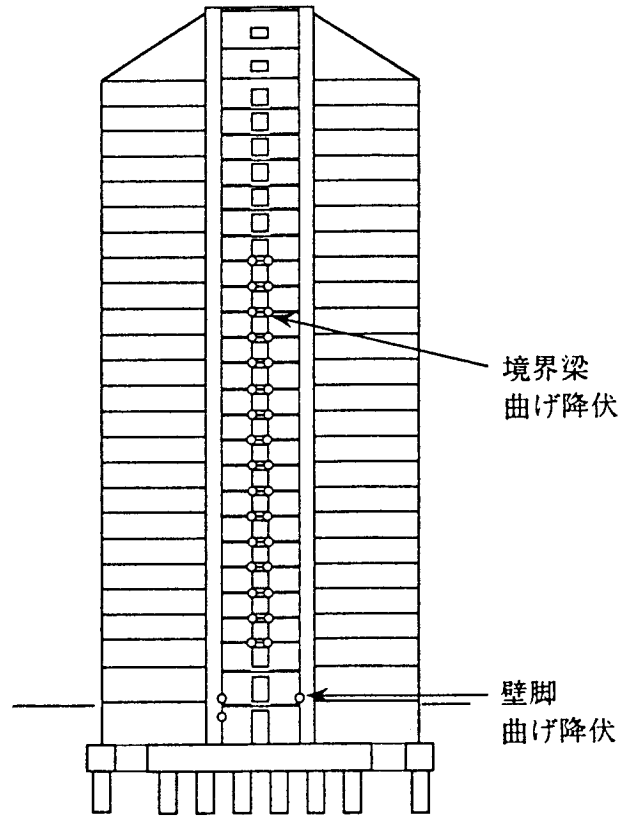

図13 ヒンジ発生情報図（X力向、レベル 2）
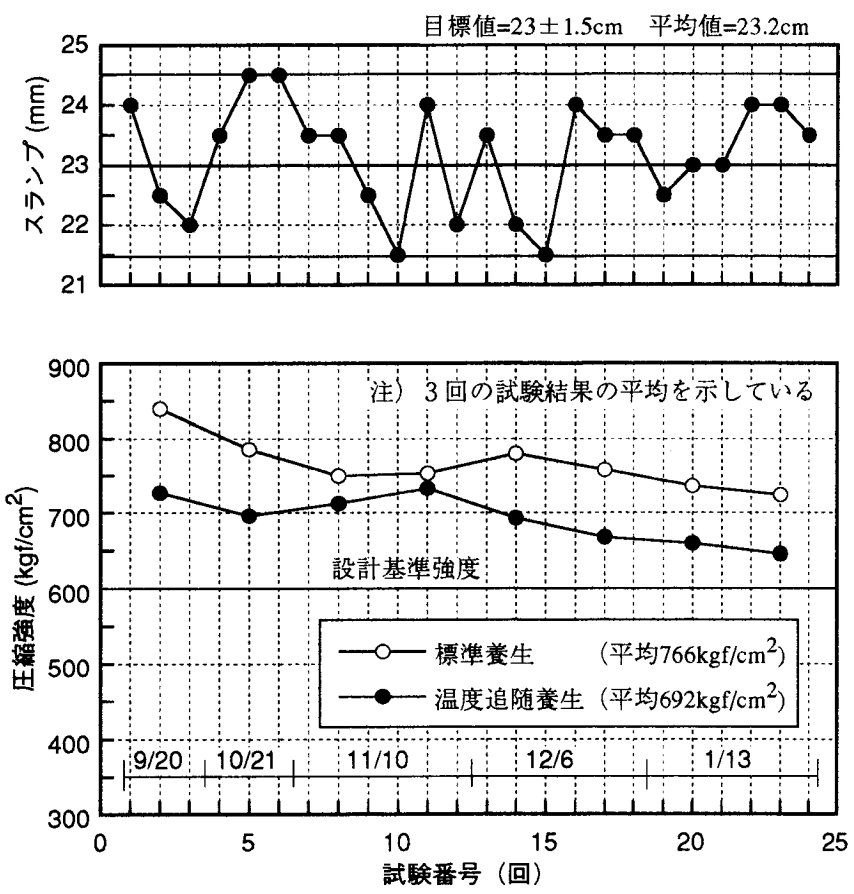

図15 実施工における品質管理試験結果 
発現状況を図 3 中に示す。水セメント比が異なるため、压縮強度は 試験練りよりも高くなっているが、強度発現状況は試験練りと同じ 傾向を示している。また打ち増し部から採取したコア供試体の圧縮 強度は平均で $779 \mathrm{kgf} / \mathrm{cm}^{2}$ であった。図15に実施工における品質管理 試験結果を示す。温度追随盖生の試験結果はすべて設計基準強度を 満足した。標準養生と温度追随養生の圧縮強度の比率は、施工期間 の平均では約1.1倍であった。

\section{4 常時微動測定結果}

本建物には R Cコアウォールと鉄骨フレームを組み合わせた新し い構造システムを用いており、それぞれの軸剛性が大きく異なるた め、固有值解析（図12参照）でも水平・上下動が連成したモードが 現われている。そこで水平動用に加え上下動用の振動計を建物内に 多数設置し、上下・水平両方向の常時微動測定を同時に行った6)。 常時微動測定は竢工半月前の内外装がほぼ完成した状況で実施した。

$\mathrm{X}, \mathrm{Y}, \mathrm{Z}$ 各方向におけるパワースペクトルから各ピーク振動数を読 みとり、この振動数に対応する振動モードを特定した。その結果を 表 2 に示す。設計用モデルの固有周期と常時微動測定によって求め た固有周期を比較すると、X方向並進 1 次モードで1.97secに対して $1.61 \mathrm{sec} 、 Y$ 方向並進 1次モードで2.02secに对して $1.69 \mathrm{sec}$ 、常時 微動測定結果のほうが20\%ほど短くなっている。これは外壁（PC カーテンウォール）による剛性の増加や、積載荷重がほとんど無い ことによる質量の減少によるものと考えられ、既往の振動測定結果 8)でも同様の傾向が得られている。上下方向のモードについては測 定された振動モードから 1 次 $(0.27 \mathrm{sec})$ は周辺フレームがコアウォー ルに関して対称に振動するモード、2次 $(0.24 \mathrm{sec})$ は周辺フレームが $\mathrm{Y}$ 軸に関して逆対称に振動するモード、3 次 $(0.15 \mathrm{sec})$ は周辺フレー ムがX軸に関して逆対称に振動するモードであると判断される。上 下 1 次が設計用モデルの Z 方向 1 次、上下 2 次が設計用モデルのX 方向 3 次に対芯するものと考えられる。

また表 2 にはハーフパワー法で求めた隇衰定数を併記した。並進 1 次モードの值（X力向 $2.7 \% 、 Y$ 方向 $1.9 \%$ ）は、同規模の鉄骨造 建物よりも大きめの值となっている。

表 2 各振動モードの固有振動数、固有周期、減衰定数測定結果

\begin{tabular}{|c|c|c|c|c|c|}
\hline モード種別 & 次数 & $\begin{array}{c}\text { 固有周期 } \\
(\mathrm{sec})\end{array}$ & $\begin{array}{c}\text { 同設計值 } \\
(\mathrm{sec})\end{array}$ & $\begin{array}{c}\text { 固有振動数 } \\
(\mathrm{Hz})\end{array}$ & 減衰定数 (\%) \\
\hline \multirow{3}{*}{$\mathrm{X}$ 方向並進 } & 1 & 1.61 & 1.97 & 0.62 & 2.7 \\
\hline & 2 & 0.41 & 0.49 & 2.46 & 3.0 \\
\hline & 3 & 0.19 & 一 & 5.40 & 1.5 \\
\hline \multirow{3}{*}{ Y方向並進 } & 1 & 1.69 & 2.02 & 0.59 & 1.9 \\
\hline & 2 & 0.44 & 0.52 & 2.27 & 2.6 \\
\hline & 3 & 0.22 & - & 4.50 & 1.4 \\
\hline \multirow{3}{*}{ ねじれ } & 1 & 1.01 & - & 0.99 & 1.6 \\
\hline & 2 & 0.34 & - & 2.92 & 1.5 \\
\hline & 3 & 0.20 & - & 5.00 & 1.1 \\
\hline \multirow{3}{*}{ 上下 } & 1 & 0.27 & 0.29 & 3.70 & 3.7 \\
\hline & 2 & 0.24 & 0.30 & 4.22 & 1.3 \\
\hline & 3 & 0.15 & 一 & 6.60 & 1.1 \\
\hline
\end{tabular}

4 おわりに

高層建築物のコア部分を鉄筋コンクリート造雱震壁とし、周边フ レームを鉄骨造とした混合構造「RＣコアウォールシステム」を開 発し、実際の建物に適用した。 R C アアゥォールに設計基準強度 $600 \mathrm{kgf} / \mathrm{cm}^{2}$ の高強度コンクリートを用い、境界梁にD4 1 (SD490) の高強度太径鉄筋をX形配筋することなどによって、本構造システ ムが優れた耐震性を保有していることが実証された。

\section{謝 辞}

本プロジェクトは、建設所、設計本部、技術研究所、建築本部な ど清水建設（株）の関連部門の総合力によって実現することができ た。また施工に関しては、厚木小野田レミコン（株）、小野田セメ ント（株）、花王（株）、山宗科学（株）に多大なご協力をいただ いた。末筆ながら関係各位に深く感謝の意を表する。

\section{参考文献}

1）西田 朗、ほか 3 名：高強度コンクリートの高層建築物への適用に関 する研究、コンクリート工学年次論文報告集、Vol.15、No.1、pp.375380、 1993

2）熊谷仁志、ほか 3 名：工事記録一R C コアウォールを用いた高層事務 所ビルー、コンクリート工学、Vol.32、No.6、pp.36-44、1994.6

3）中島秀雄、ほか：RCコアウォールシステムの寒用化に関する研究 （その1４）、日本建築学会大会学術講演梗概集、Vol.C、pp.449456、1992.8

4）中島秀雄、ほか：プレートに浴接されたアンカーボルトの押抜きせん 断実験、日本建築学会大会学術講演梗概集、Vol.C、pp.1889-1890、 1992.9

5) 今井三雄、ほか 3 名：RCコアウォールシステムを用いた高層事務所 ビルの設計（仮称）海老名計画、ビルディングレター、pp.9-14、 1992.12

6）佐武直紀、中島秀雄：水平 ·上下動同時測定に上る高層建物の振動特 性評価、日本建築学会関東支部研究報告集、pp.61-64、1995

7）内山義次、ほか 4 名：テクニカルレポートー3 次元データを利用した 施工計画／管理支援システムの開発一、施工、pp.55-66、1995.2

8）横田治彦、佐武直紀、岡田敬一：掓動試験および地震観測デー夕に基 ごく鉄骨造高層建物の減衰性状、日本建築学会構造系論文報告集第453 号、pp.77-84、1993.11

9）日本建築学会：鉄筋コンクリート造建物の終局強度型耐震設計指針． 同解説、 1990

[1996 年 6 月 25 日原稿受理 1996 年 9 月 10 日採用決定］ 